V.V. Trachevskiy ${ }^{1,3}$, M.T. Kartel ${ }^{1,2}$, Wang Bo ${ }^{1}$

\title{
THERMAL AND ELECTRICAL CHARACTERIZATION OF POLYMER/CARBON NANOTUBES COMPOSITES WITH POLYVINYL BUTYRAL MATRIX
}

\author{
${ }^{1}$ Ningbo University of Technology \\ No 55-155 Cui Bai Road, Ningbo, 315016, China \\ ${ }^{2}$ Chuiko Institute of Surface Chemistry of National Academy of Sciences of Ukraine \\ 17 General Naumov Str., Kyiv, 03164, Ukraine \\ ${ }^{3}$ Institute of Macromolecular Chemistry of National Academy of Sciences of Ukraine \\ 48 Kharkivske Road,Kyiv,02160,Ukraine,E-mail: meches@ukr.net
}

\begin{abstract}
The rapid development of modern technology requires new materials with predetermined properties. There is a need for materials with ultra-high strength, hardness, other characteristics and a common combination of these properties. The work was aimed at solving the problem of creating polymer composite materials that combine high physical and mechanical characteristics and thermal and electrical conductivity. Information was given on fillers, the use of which gives polymers thermal and electrical properties. Shown are the most commonly used in the composition of polymer composites fillers, advantages and disadvantages of each of the fillers. It was established that the use of carbon nanotubes allows obtaining polymer composites with the required performance characteristics. One of the problems when using nanoparticles as modifiers of reactive oligomers is their uniform distribution in the volume of the polymer matrix. Heterogeneity and uneven distribution of the dispersed phase can lead to dangerous defects in the material, so the technology of combining the nanofillers and the polymer matrix plays an important role. The possibility of obtaining polyvinyl butyral structured with carbon nanotubes in the process of its synthesis in the presence of carbon nanotubes was shown and the technological conditions of In situ synthesis are developed. Experimental samples of polyvinyl butyral structured with carbon nanotubes with high thermal and electrically conductive characteristics were obtained. Under optimal conditions of synthesis, in the obtained PVB samples structured with carbon nanotubes, the electrical conductivity of the composite increases by five orders of magnitude due to the high electrical conductivity of CNTs. For the obtained PVB, structured with carbon nanotubes, the fracture stress was significantly (by $62 \%$ ) increased, and the fracture deformation is reduced by approximately $38 \%$. The decrease in the deformation of the fracture during compression indicates an increase in the fragility of the polymer with the inclusion of CNTs. The prospects for the synthesis of polyvinyl butyral in the presence of carbon nanotubes to obtain a composite with a high level of achieved electrical and thermal conductivity were shown.
\end{abstract}

Keywords: composite materials, thermal conductivity, electrical conductivity, carbon nanotubes, polyvinyl butyral

\section{INTRODUCTION}

The present time is characterized by high rates of scientific and technological progress. The rapid development of modern technology requires more and more new materials with predetermined properties. There is a need for materials with ultra-high strength, hardness, other characteristics and a combination of these properties. Therefore, the main and long-term direction in the development of new materials now consists in creating materials by combining various already known materials, that is, in obtaining composite materials [1].

Polyvinyl butyral (PVB) is a polymer widely used as an interlayer in laminated safety glass for automobile windshields. Recently it has also been found application in photovoltaic solar cell encapsulation. Other applications include as hot melt adhesive, ultra filtration membranes, radio-chromic film dosimeter etc. It has excellent optical properties like transparency, low glass transition temperature and mechanical properties like strong adhesion, flexibility etc. As an encapsulating material, polyvinyl butyral protects the encapsulated material from degradation due to environmental influences. It has good resistance to heat, UV light and moisture permeation. It is usually prepared by modifying the already existing polymer chain of polyvinyl alcohol. PVB has amorphous structure at room temperature and its thermal conductivity $(0.0224 \mathrm{~W} / \mathrm{M} \cdot \mathrm{K})$ falls in 
the lower end among different polymers. The volume resistivity of PVB is around $10^{13} \Omega \cdot \mathrm{m}$ level.

Oligomers and polymers, which are used as a basis of adhesives, are dielectrics in the cured state and do not conduct electric current. However, in various branches of technology, it is required to provide electrical contact between the surfaces to be joined through the use of electrically conductive adhesives. Such adhesives are most in demand in instrument making and electronics. In aviation and rocketry, they are used in adhesive joints of structures to remove static electricity. To ensure electrical conductivity, special fillers are introduced into the adhesives, while the level of electrical conductivity depends on the type and amount of filler used.

Most often, conductive fillers are used in conductive adhesives: graphite, carbon black, carbonyl nickel, and finely dispersed metal powders. Common to all conductive adhesives is a high filling rate. Analysis of scientific, technical and patent literature in the leading countries of the world: Russia, USA, Japan, Germany, France, Great Britain and China with a retrospective search for 27 years has shown that the highest electrical conductivity is provided by finely dispersed metal powders, which are introduced in quantities of 2-3 times exceeding the weight of the polymer. The specific volumetric electrical resistance of such systems reaches $10^{-5}-10^{-6} \Omega \cdot \mathrm{m}$. Conductive fillers also include powders from metals and their alloys with magnetic properties, for example, powders obtained from a rapidly quenched hard magnetic alloy neodymium - iron - boron. An adhesive with such a filler ensures self-fixation of substrates with a sufficiently high compression force. Silver powders are most commonly used in conductive adhesives. Due to their high plasticity and resistance to oxidation, silver particles form strong contacts that are resistant to high temperatures, moisture and various components of polymer adhesives, which do not change under operating conditions [2,3].

Recently, the trend of using nanostructuring additives as modifiers in the manufacture of composite materials for various industries, including aircraft construction, has been dynamically developing [4-11].

Multiwall carbon nanotubes are among the most anisotropic materials known and have extremely high values of Young's modulus [12]. Carbon nanotube aspect ratio of length to diameter is more than $10^{3}$; this distinguishes it from other nanoparticles. New composites with carbon nanotubes (CNTs) as additives were studied intensively during the last decade. Composites are characterized by extremely high specific strength properties, electrical and thermal conductivity.

CNT are characterized by extremely high specific strength characteristics (tensile strength $\approx 1.8 \mathrm{TPA}$ ), electrical and thermal conductivity, etc. In this connection, they have great prospects for use in modern technologies. The property that distinguishes CNT from other nanoparticles is the uniquely high aspect ratio $(\eta)$ (ratio of length to diameter) that exceeds $10^{3}$. In this case, the percolation threshold $\Phi_{\eta}\left(\Phi_{\eta} \approx 1 / \eta\right)$, that is, the concentration at which A continuous grid of CNTs is formed, provided they are uniformly distributed in the polymer matrix, can be $\approx 0.1 \%$ by weight.

One of the acute problems in the use of nanoparticles as modifiers of reactive oligomers is their uniform distribution in the bulk of the material. Inhomogeneity and uneven distribution of the dispersed phase can lead to the appearance of dangerous defects in the material, therefore, the technology of combining nanofillers and polymer plays an important role.

The main methods of introducing nanoparticles into polymers include:

1) Direct mixing of polymer and nano-particles;

2) In situ polymerization in the presence of nanoparticles. The most common and simplest method is the first method for producing composites.

To achieve a high degree of uniform distribution of particles, it is proposed to use various types of processing and their combinations: signification, high-speed shear, the addition of surfactants. There are various methods for obtaining nanocomposites: in the process of synthesis, in solution, in a melt, deposition on a reinforcing filler, and using sol-gel technology.

The authors of [13] obtained polymer composites CNT - PVB from solution using solvents ethanol and 1-butanol with vigorous stirring and sonication. However, this method does not provide sufficient dispersion of CNTs in the polymer matrix, which makes it impossible to obtain the required performance characteristics of the composite.

The aim of this work was to obtain conductive compositions based on polyvinyl butyral structured with carbon nanotubes. 


\section{EXPERIMENTAL}

\section{Synthesis of polyvinyl butyral modified with} carbon nanotubes. Polyvinyl butyral is produced by the interaction of butyraldehyde and polyvinyl alcohol in an aqueous medium in the presence of a dispersion of carbon nanotubes (CNTs). The optimum determined amount of CNTs is $0.5 \mathrm{wt}$. \% of the resulting polymer. The synthesis was carried out at the temperature of $70{ }^{\circ} \mathrm{C}$ for $30 \mathrm{~min}$.

CNTs were obtained by the method of catalytic chemical vapour deposition (CCVD) by pyrolysis of hydrocarbons on complex metal oxide catalysts. Synthesis of CNT was carried out in equipment with a reactor volume of $30 \mathrm{dm}^{3}$ and an output of about $1.5 \mathrm{~kg}$ of product per day. According to the Ukrainian standard (TU U 24.103291669-009: 2009 (ISC NAS of Ukraine)), the average diameter of the CNT was 10-20 $\mathrm{nm}$, the specific surface determined by desorption of argon was $200-400 \mathrm{~m}^{2} / \mathrm{g}$, the bulk density - within $20-40 \mathrm{~g} / \mathrm{cm}^{3}[14-15]$.

The temperature dependence of the thermal conductivity of the samples was measured by the method of dynamic heating using an IT- $\lambda-400$ industrial device equipped with an analogy-digital device for recording data on a personal computer. The samples were coated with a thin layer of graphite grease to improve thermal contact with the measuring plates. The measurements were carried out in the temperature range $40-170{ }^{\circ} \mathrm{C}$ with a heating rate of $5{ }^{\circ} \mathrm{C} / \mathrm{min}$. The relative error of the method was $\pm 8 \%$.
The electrical conductivity at low frequencies at room temperature was investigated by a twocontact method using an E7-14 immittance meter. The tests were carried out on a 2167-P50 tensile testing machine in the mode of repeated-static compression with a record of the deformation diagram until the final destruction of the sample. The fibres were fixed by winding them onto cylindrical clamps. The loading speed was $10 \mathrm{~mm} / \mathrm{min}$.

The structural features and crystallization behaviour of nanocomposites, as well as the dependence on CNTs, were investigated by differential thermal and gravimetric analyses (DTA, DTG) (Q1500 derivatograph, heating rate $10{ }^{\circ} \mathrm{C} / \mathrm{min}$ ).

The results of the analysis of the DTA diagrams of the sample are given in Table 1: the temperature of the beginning and end of the melting and crystallization process, the temperature range of these processes, as well as the temperature of the extreme of the DTA peak. The results showed that the characteristic temperatures of the melting process depended on the presence of CNTs. The limited mobility of polymer units, which can be caused by the interaction of the polymer with the filler surface, is obviously the reason for the increase in the melting and crystallization temperatures. For crystallization processes, a monotonic but nonlinear increase in characteristic temperatures is observed. This is due to the presence of CNTs in the polymer material.

Table 1. Characteristic samples temperatures

\begin{tabular}{|c|c|c|c|c|c|c|c|c|c|c|}
\hline \multirow[b]{2}{*}{$\mathbf{N}$} & \multirow[b]{2}{*}{ System } & \multicolumn{4}{|c|}{ Melting process } & \multicolumn{4}{|c|}{ Crystallization process } & \multirow[b]{2}{*}{ Crystallinity, \% } \\
\hline & & $\begin{array}{l}T_{\text {s., }} \\
{ }^{\circ} \mathrm{C}\end{array}$ & $\begin{array}{l}\boldsymbol{T}_{\mathrm{m}} ., \\
{ }^{\circ} \mathbf{C}\end{array}$ & $\begin{array}{l}T_{\text {e., }} \\
{ }^{\circ} \mathbf{C}\end{array}$ & $\begin{array}{l}\Delta \boldsymbol{\Delta}, \\
{ }^{\circ} \mathbf{C}\end{array}$ & $\begin{array}{l}\boldsymbol{T}_{\text {s., }} \\
{ }^{\mathbf{C}}\end{array}$ & $\begin{array}{l}T_{\mathrm{m} .,} \\
{ }^{\circ} \mathbf{C}\end{array}$ & $\begin{array}{l}T_{e} \\
{ }^{\circ} \mathbf{C}\end{array}$ & $\begin{array}{l}\Delta T, \\
{ }^{\circ} \mathrm{C}\end{array}$ & \\
\hline 1 & PVB & 163 & 180 & 192 & 29 & 136 & 120 & 101 & 35 & 72.1 \\
\hline 2 & $\mathrm{PVB}+\mathrm{CNT}$ & 168 & 181 & 199 & 31 & 141 & 126 & 104 & 37 & 74.9 \\
\hline
\end{tabular}

The crystallization temperature in the PVB-CNT system increases, and the temperature range $(\Delta T)$ of melting and crystallization is shorter in comparison with pure PVB. This may indicate a similar nature of the effect of CNTs on the processes of structure formation of composites.

The electrical conductivity at low frequencies at room temperature was investigated by the twocontact method using an E7-14 immittance meter. With the content of CNTs, separate leading chains are formed from agglomerates of the filler. In the studied sample, the electrical conductivity of the composite increases by 5 orders of magnitude due to the high electrical conductivity of CNTs. A jump in the dielectric constant is also observed, the dependence of which is presented in the form of the Clausius-Mosotti function:

$$
\left(F=\frac{\varepsilon-1}{\varepsilon+2}\right),
$$


where $\varepsilon$ is the dielectric constant.

The measured value of $\varepsilon$ is 10 , respectively $F-0.75$ relative units. This shows that structural features are observed in the percolation transition, that is, in a system where there is still no continuous CNT cluster.

The level of thermal conductivity of the composites of the system is rather low, since the polymer, a feature of which is a complex molecular and supramolecular structure, makes the main contribution to the total thermal conductivity. It is known that the thermal conductivity of polymer composites depends not only on the thermal conductivity of the filler, concentration and tendency to form intrinsic structures in the composite material, but also on the level of its interaction with the polymer matrix.

The heat resistance of thermoplastics characterizes the plasticity of the polymer at a given temperature and significantly depends on the molecular weight, degree of crystallinity and technological conditions for obtaining the polymer material. It increases with an increase in the degree of crystallinity of the polymer. A change in this temperature in the system may indicate the state of the supramolecular structure of the polymer component in the temperature range under consideration. The temperature dependences of the thermal conductivity of the PVB - CNT and PVB system are given in Table 2.

Table 2. Temperature dependences of thermal conductivity

\begin{tabular}{cccccccc}
\hline & $\boldsymbol{T},{ }^{\circ} \mathbf{C}$ & $\mathbf{2 0}$ & $\mathbf{4 0}$ & $\mathbf{6 0}$ & $\mathbf{8 0}$ & $\mathbf{1 0 0}$ & $\mathbf{1 2 0}$ \\
\hline $\mathrm{PVB}$ & $\lambda, \mathrm{W} / \mathrm{M} \cdot \mathrm{K}$ & 0.011 & 0.015 & 0.017 & 0.016 & 0.015 & 0.014 \\
$\mathrm{PVB}+\mathrm{CNT}$ & $\lambda, \mathrm{W} / \mathrm{M} \cdot \mathrm{K}$ & 0.31 & 0.37 & 0.35 & 0.34 & 0.33 & 0.32 \\
\hline
\end{tabular}

The data on the dependence of the compressive stress and deformation in a pure polyvinyl butyral sample and a sample modified with carbon nanotubes are given in Table 3 .

When CNTs are added to PVB, the fracture stress increases significantly (by $62 \%$ ), and the fracture strain decreases by about $38 \%$. A decrease in the deformation of fracture in compression indicates an increase in the brittleness of the polymer when CNTs are included.
Thus, polymer compositions reinforced with carbon nanotubes have characteristic temperatures of the melting process, which depend on the presence of CNTs. The limited mobility of polymer units, which can be caused by the interaction of the polymer with the filler surface, is obviously the reason for the increase in the melting and crystallization temperatures.

Table 3. Compressive stress versus deformation

\begin{tabular}{ccccccccc}
\hline \multicolumn{10}{c}{ PVB } \\
\hline Compression stress, MPa & 0 & 5 & 10 & 15 & 20 & 25 & 30 & 35 \\
Deformation, \% & 0 & 1.3 & 1.7 & 2.1 & 2.3 & 3.3 & 4.5 & 5.6 \\
\hline & & & PVB+CNT & & & & & \\
\hline Compression stress, $\mathrm{MPa}$ & 0 & 5 & 10 & 15 & 20 & 25 & 30 & 35 \\
Deformation, \% & 0 & 0.3 & 0.5 & 0.6 & 0.7 & 1.2 & 1.5 & 1.8 \\
\hline
\end{tabular}

The crystallization temperature in the PVB-CNT system increases and the temperature range $(\Delta T)$ of melting and crystallization is shorter in comparison with pure PVB. This may indicate a similar nature of the effect of CNTs on the processes of structure formation of composites.

In the studied sample, the electrical conductivity of the composite increases by 5 orders of magnitude due to the high electrical conductivity of CNTs. 


\section{CONCLUSIONS}

1. The possibility of obtaining polyvinyl butyral structured with carbon nanotubes in the process of its synthesis in the presence of carbon nanotubes has been shown.
2. The efficiency of the introduction of carbon nanotubes into the polymer matrix to improve the physicochemical, physic mechanical and operational characteristics has been shown.

\title{
Теплова та електрична характеристики композитів полімер/вуглецеві нанотрубки 3 полівінілбутиральною матрицею
}

\author{
В.В. Трачевський, M.T. Картель, Wang Bo \\ Ningbo University of Technology \\ No 55-155 Cui Bai Road, Ningbo, 315016, China \\ Інститут хімії поверхні ім. О.О. Чуйка Наџіональної академії наук України \\ вул. Генерала Наумова, 17, Київ, 03164, Україна \\ Інститут хімії високомолекулярних сполук Національної академії наук України \\ Харківське шосе, 48, Київ, 02160, Україна, тесhеs@ukr.net
}

\begin{abstract}
Бурхливий розвиток сучасної техніки вимагає все нових матеріалів з наперед заданими властивостями. Виникає потреба в матеріалах з надвисокою міцністю, твердістю, іншими характеристиками $і$ спільним поєднанням цих властивостей. Робота спрямована на вирімення проблеми створення полімерних композиційних матеріалів, які поєднують високі фізико-механічні характеристики та тепло- $i$ електропровідність. Наводяться відомості по наповнювачах, застосування яких надає полімерам тепло- та електропровідні властивості. Показані найбільш часто використовувані в складі полімерних композитів наповнювачі, переваги і недоліки кожного з наповнювачів. Встановлено, щзо використання вуглецевих нанотрубок дозволяе отримати полімерні композити з необхідними експлуатаційними характеристиками. Однією з проблем при використанні наночастинок як модифікаторів реакиійноздатних олігомерів $є$ їхній рівномірний розподіл в об'ємі полімерної матриці. Неоднорідність і нерівномірність розподілу дисперсної фази може призводити до виникнення небезпечних дефектів в матеріалі, тому технологія сумімення нанонаповнювача $i$ полімерної матриці відіграє важливу роль. Показана можливість отримання полівінілбутиралю, структурованого вуглецевими нанотрубками, в процесі його синтезу в присутності вуглецевих нанотрубок та розроблені технологічні умови синтезу In situ. Отримано експериментальні зразки полівінілбутиралю, структурованого вуглецевими нанотрубками, з високими тепло- $і$ електропровідними характеристиками. За оптимальних умов проведення синтезу, у отриманих зразків ПВБ, структурованих вуглецевими нанотрубками, електропровідність композиту збільшується на 5 порядків величини внаслідок високої електропровідності УНТ. Для отриманого ПВБ, структурованого вуглечевими нанотрубками, напруга руйнування значно (на 62 \%) збільшуються, а деформачія руйнування зменшується приблизно на $38 \%$. Зменшення деформащії руйнування при стискуванні свідчить про збільшення крихкості полімера при включенні УНТ. Показано перспективність синтезу полівінілбутиралю в присутності вуглецевих нанотрубок для отримання композиту з високим рівнем електро- і теплопровідності.
\end{abstract}

Keуwords: композитні матеріали, теплопровідність, електропровідність, вуглецеві нанотрубки, полівінілбутираль 


\section{REFERENCES}

1. Pizzi A., Mittal K.L. Handbook of Adhesive Technology, Second Edition, Revised and Expanded. (Marcel Dekker Inc., 2003).

2. Ebnesajjad S. Handbook of Adhesives and Surface Preparation: Technology, Applications and Manufacturing. (Elsevier, 2010).

3. Kutsevich K.E., Tyumeneva T.Yu., Petrova A.P. Influence of fillers on properties of adhesive prepregs and PCM on their basis. Aviation Materials and Technologies. 2017. 4(49): 51. [in Russian].

4. Petrova A.P., Lukina N.F., Pavlyuk B.F., Isaev A.Yu., Besednov K.L. Fillers for conductive adhesives. Novosti materialovedeniya. Nauka i tekhnika. 2017. 5-6(28): 47. [in Russian].

5. Faddoul R., Reverdy-Bruas N., Bourel J. Silver content effect on rheological and electrical properties of silver pastes. J. Mater. Sci.: Mater. Electron. 2012. 23: 1415.

6. Zhang D.L., Zha J.W., Li C.Q., Li W.K., Wang S.J., Wen Y., Dang Z.M. High thermal conductivity and excellent electrical insulation performance in double-percolated three-phase polymer nanocomposites. Compos. Sci. Technol. 2017. 144: 36.

7. Ahmad J., Bazaka K., Anderson L.J., White R.D., Jacob M.V. Materials and methods for encapsulation of OPV: a review. Renewable Sustainable Energy Rev. 2013. 27: 104.

8. Burger N., Laachachi A., Ferriol M., Lutz M., Toniazzo V., Ruch D. Review of thermal conductivity in composites: mechanisms, parameters and theory. Prog. Polym. Sci. 2016. 61: 1.

9. Handge U.A., Wolff M.F.H., Abetz V., Heinrich S. Viscoelastic and dielectric properties of composites of poly(vinyl butyral) and alumina particles with a high filling degree. Polymer. 2016. 82: 337.

10. Taherian R. Experimental and analytical model for the electrical conductivity of polymer-based nanocomposites. Compos. Sci. Technol. 2016. 123: 17.

11. Kuang Y., Huang B. Effects of covalent functionalization on the thermal transport in carbon nanotube/polymer composites: a multi-scale investigation. Polymer. 2015. 56: 563.

12. Treacy M.M.J., Ebbesen T.W., Gibson J.M. Exceptionally high Young's modulus observed for individual carbon nanotubes. Nature. 1996. 381: 678.

13. Castellino M., Tortello M., Bianco S., Musso S., Giorcelli M., Pavese M., Gonnelli R.S., Tagliaferro A. Thermal and electronic properties of macroscopic multi-walled carbon nanotubes blocks. J. Nanosci. Nanotechnol. 2010. 10: 3828 .

14. Patent UA 15733. Yanchenko V.V., Sementsov Yu.I., Melezhik O.V. A method of obtaining carbon nanomaterials. 2006. [in Ukrainian].

15. Ukrainian Standard. Carbon nanotubes. TU U 24.103291669-009:2009. 2009. [in Ukrainian]. 